\title{
Microbial Synthesis of Folate Polyglutamates from Labelled Precursors
}

\author{
By J. P. BROWN, F. DOBBS, GILLIAN E. DAVIDSON \\ AND J. M. SCOTT \\ Department of Biochemistry, Trinity College, Dublin 2, Irish Republic
}

(Received 26 March 1974)

\begin{abstract}
SUMMARY
The uptake and synthesis of folate polyglutamates from $\left[{ }^{3} \mathrm{H}\right]$ pteroylglutamic acid and $\left[{ }^{14} \mathrm{C}\right] p$-aminobenzoic acid was studied in Lactobacillus casei, Streptococcus faecalis, L. plantarum and Escherichia coli. The analytical techniques were based on oxidative or hydrolytic degradation of the folate compounds followed by chromatographic separation of the resulting mixtures of pteroylglutamate derivatives or $p$-aminobenzoylpoly- $\gamma$-L-glutamates and comparison with appropriate synthetic standards. All four organisms synthesized numerous polyglutamate derivatives from the precursors provided. The large majority $(85$ to $95 \%)$ of folates of lactobacilli were polyglutamates with more than seven glutamyl residues; $L$. casei formed several such unidentified long-chain components. In contrast, $E$. coli and particularly $S$. faecalis synthesized mainly polyglutamates with seven or less glutamate residues; tetra-, hexa- and heptaglutamates were tentatively identified in E. coli, and tri-, tetra- and pentaglutamates in $S$. faecalis. While L. case $i$ appeared to synthesize a mixture of formyl- and methyltetrahydro derivatives, formyltetrahydro derivatives predominated in $E$. coli and $S$. faecalis.
\end{abstract}

\section{INTRODUCTION}

Understanding of the early steps in the microbial synthesis of folate compounds is largely based on the work of Brown and co-workers with E. coli (Brown, Weisman \& Molnar, I96I; Reynolds \& Brown, I964; Weisman \& Brown, I964; Griffin \& Brown, 1964). While these authors' findings in vitro support a path yielding successively dihydropteroate $\left(\mathrm{H}_{2} \mathrm{Pte}\right)$, dihydropteroylglutamate $\left(\mathrm{H}_{2} \mathrm{PteGlu}\right)$, tetrahydropteroylglutamate $\left(\mathrm{H}_{4} \mathrm{PteGlu}\right)$, tetrahydropteroyldiglutamate $\left(\mathrm{H}_{4} \mathrm{PteGlu}\right)$ and $\mathrm{H}_{4} \mathrm{PteGlu}_{3}$-triglutamate in this species, it is still somewhat uncertain whether $\mathrm{H}_{2}$ Pte is an obligatory intermediate in vivo. This pathway is also thought to operate in L. plantarum (Shiota \& Disraely, 1961), in micrococci (Merola \& Koft, I960) and in yeast (Jaenicke \& Chan, 1960). A pathway involving $p$-aminobenzoylglutamate ( $p$-ABGlu) probably predominates in pneumococci (Ortiz \& Hotchkiss, 1966) and perhaps in Mycobacterium avium (Katsunuma \& Shoda, 1958). Recently Martin \& Koft (1972) have observed the formation of rhizopterin (I0-HCO-Pte) and formylated pteroyldiand pteroyltriglutamates during the growth of Staphylococcus epidermidis, thus suggesting a novel biosynthetic pathway presumably independent of a dihydropteroate $\left(\mathrm{H}_{2} \mathrm{Pte}\right)$ or tetrahydropteroate $\left(\mathrm{H}_{4} \mathrm{Pte}\right)$.

The nature of the folate polyglutamate end products of these biosynthetic routes has been difficult to establish, mainly because of the large number of possible derivatives, their small quantity and unfavourable chromatographic properties (Baugh \& Krumdieck, 197I; Shin, Buehring \& Stokstad, 1972). Only in yeast and Clostridium acidi-urici have the number of glutamyl residues present in the folate compounds been unequivocally deter- 
mined, yeast containing primarily heptaglutamate derivatives (Pfiffner, Calkins, Bloom \& O'Dell, 1946) and C. acidi-urici pteroyltriglutamates (Curthoys, Scott \& Rabinowitz, I972). In the present study labelled folate polyglutamates synthesized from $\left[{ }^{3} \mathrm{H}\right]$ pteroylglutamic acid by $L$. casei and $S$. faecalis and from $p$-amino $\left[{ }^{14} \mathrm{C}\right]$ benzoic acid by $L$. plantarum and Escherichia coli were extracted and analysed following either oxidative or hydrolytic degradation.

\section{METHODS}

Organisms. Streptococcus (lactis) faecalis R NCIB6459, L. casei var. rhamnosus NCIBI0463, $L$. plantarum (arabinosus I7-5) NCIB6376, and $E$. coli NCIB8I09 were obtained from the National Collection of Industrial Bacteria, Torry Research Station, Aberdeen.

Media and growth conditions. Streptococcus faecalis was carried on stock cultures of Bacto micro assay culture agar (Difco) and inoculated by loop into $50 \mathrm{ml}$ of sterile Bacto folic acid casei medium (Difco) containing a nearly limiting concentration of [ $\left.{ }^{3} \mathrm{H}\right]$ pteroylglutamic acid of $3.2 \mathrm{ng}$ and $0.2 \mu \mathrm{Ci} / \mathrm{ml}$. The culture was incubated for 20 to $24 \mathrm{~h}$ at $37^{\circ} \mathrm{C}$ to obtain organisms in the stationary phase of growth.

A chloramphenicol-resistant strain of $L$. casei originally described by Millbank, Davis, Rawlins \& Waters (1970) and employed in routine microbiological assay in this laboratory (O'Broin, Scott \& Temperley, 1973) was carried on stock cultures of folic acid assay PGA broth (BBL, Cockeyville, Maryland, U.S.A.) containing I \% noble agar (Difco), pteroylglutamic acid (O.I ng/ml), and chloramphenicol (Chloromycetin, Parke-Davis, Hounslow; $20 \mu \mathrm{g} / \mathrm{ml}$ ). Inoculation from a similarly composed broth culture was made into 21 of broth containing $\left[{ }^{3} \mathrm{H}\right]$ pteroylglutamic acid $(0.2 \mathrm{ng}$ or $5 \mathrm{nCi} / \mathrm{ml})$ and the culture was incubated for $48 \mathrm{~h}$ at $37^{\circ} \mathrm{C}$ to obtain stationary phase organisms.

A $p$-aminobenzoate-requiring mutant of $E$. coli (Lampen, Jones \& Roepke, 1949) was cultured in a basal synthetic medium composed of the following $(\mathrm{g} / \mathrm{l}): \mathrm{NaCl}, 2.94 ; \mathrm{NH}_{4} \mathrm{Cl}$, $2 \cdot 66 ; \mathrm{KH}_{2} \mathrm{PO}_{4}, 3 \cdot 4 ; \mathrm{CaCl}_{2}, 7 \cdot 4 \times \mathrm{IO}^{-3} ; \mathrm{MgSO}_{4}, 0 \cdot 25 ;$ glucose, $2 \cdot 0 ; p$-aminobenzoate, $4 \times 10^{-6}$; $\mathrm{pH} 7 \cdot 2$. Two $1(4 \times 0.51)$ sterile basal medium containing $6 \mu \mathrm{g}$ or $5 \mu \mathrm{Ci} p$-amino $\left[{ }^{14} \mathrm{C}\right]$ benzoate were inoculated with $0.1 \mathrm{ml}$ from a broth culture and incubated on a reciprocating shaker, at $37^{\circ} \mathrm{C}$ for 24 to $36 \mathrm{~h}$ to provide stationary phase organisms.

Lactobacillus plantarum, a test organism for the assay of $p$-aminobenzoic acid, was stored on Bacto micro assay culture agar and grown in the assay medium recommended by Lewis (1942) except that it was found necessary to treat 'vitamin-free' casein hydrolysate (enzymic) (Nutritional Biochemicals Corp. Cleveland, Ohio, U.S.A.) four times with $0.45 \%$ charcoal (Norit $\mathrm{A}$; Sigma) at $\mathrm{pH} 3$ for 15 min each at room temperature. The medium (I00 ml) containing $0.2 \mu \mathrm{g}$ or $0.5 \mu \mathrm{Ci} p$-amino $\left[{ }^{14} \mathrm{C}\right]$ benzoate was inoculated from a broth culture and incubated for 36 to $48 \mathrm{~h}$ at $37^{\circ} \mathrm{C}$.

Chemicals. $p$-Aminobenzoic acid ( $p$-AB) was purchased from Koch-Light Laboratories Ltd. $p$-Aminobenzoyl-L-glutamic acid ( $p$-ABGlu) was obtained from Sigma, and pteroylglutamic acid (PteGlu) from Cyanamid of Great Britain, Gosport, Hampshire. Calcium leucovorin $\left(5-\mathrm{HCO}-\mathrm{H}_{4} \mathrm{PteGlu}\right)$ was a gift from Lederle Division, American Cyanamid, Pearl River, New York, U.S.A. $\mathrm{H}_{4}$ PteGlu was prepared from PteGlu by reduction with $\mathrm{NaBH}_{4}$ (Blair \& Saunders, 1970 ); I0-HCO-H by acidification to form 5, I0-methylidyne tetrahydropteroylglutamic acid $(5,10-\mathrm{CH}=$ $\mathrm{H}_{4}$ PteGlu) and subsequent neutralization with alkali (Brown, Scott, Foster \& Weir, 1973). Pteroic acid (Pte) was prepared and purified as described previously (Houlihan, Boyle \& Scott, 1972). Pteroyl poly- $\gamma$-L-glutamates $\left(\right.$ PteGlu $\left._{2-7}\right)$ were prepared by the solid-phase method (Krumdieck \& Baugh, 1969; Baugh, Stevens \& Krumdiek, 1970). Quantitative, 
oxidative or reductive cleavage of the $\mathrm{C}_{9}-\mathrm{N}_{1}$ o bond (Freed, I966) yielded the corresponding polyglutamates of $p$-aminobenzoylglutamate $\left(p-\mathrm{ABGlu}_{2-7}\right)$.

$\left[{ }^{3} \mathrm{H}\right]$ Pteroylglutamic acid, ${ }_{5} \mathrm{Ci} / \mathrm{mmol} ;\left[{ }^{2-}{ }^{14} \mathrm{C}\right] \mathrm{PteGlu}, 55 \mathrm{mCi} / \mathrm{mmol} ; 5^{-14} \mathrm{CH}_{3} \mathrm{H}_{4} \mathrm{PteGlu}$, $54 \mathrm{mCi} / \mathrm{mmol}$; and pteroylhexaglutamyl $\left(\left[\mathrm{U}-{ }^{14} \mathrm{C}\right]\right.$ glutamic acid; PteGlu $\left.{ }_{7}\right), \mathrm{I} \cdot 2 \mathrm{mCi} / \mathrm{mmol}$, were obtained from the Radiochemical Centre, Amersham, Buckinghamshire. $p$-Amino $\left[{ }^{14} \mathrm{COOH}\right]$ benzoic acid $(52 \mathrm{mCi} / \mathrm{mmol})$ was obtained from Schwarz/Mann, Orangeburg, New York, U.S.A.

Diethylaminoethylcellulose (Whatman DE52) was purchased from W. \& R. Balston Ltd, Maidstone, Kent. QAE (quarternary ammonium exchanger) Sephadex A25 was obtained from Pharmacia. Triton X-IOo (Rohm \& Haas) was purchased from BDH, and the scintillation chemicals 2,5-diphenyloxazol (PPO) and 2,2'-p-phenylen-bis-(4-methyl-5-phenyloxazol) (POPOP) from Intertechnique Ltd, Sussex.

Extraction of folates. The bacteria were collected by centrifugation $(6000 \mathrm{~g}$, $10 \mathrm{~min})$, suspended in $0.9 \% \mathrm{NaCl}$ solution and re-sedimented. The wash was combined with the supernatant medium and samples taken for radioactivity determination. Washed organisms were suspended in $20 \mathrm{ml}$ of $0 . \mathrm{I}$ M-phosphate buffer $\mathrm{pH} 7.0$ containing $0.5 \%$ ascorbate and the suspension was autoclaved at $\mathrm{I} 2 \mathrm{I}{ }^{\circ} \mathrm{C}$ for 5 to $\mathrm{IO} \mathrm{min}$. The debris was collected by centrifugation and samples of it, as well as the supernatant extract, were removed for radioactivity counting. The extract was then divided into three or four portions, one of these usually being chromatographed, without further treatment, on QAE Sephadex as described below.

Degradation and chromatography of extracts. (i) Permanganate oxidation. To one portion of the extract was added $2.0 \%(\mathrm{w} / \mathrm{v}) \mathrm{KMnO}_{4}(4: \mathrm{r}, \mathrm{v} / \mathrm{v})$ and the $\mathrm{pH}$ was adjusted to 9.0 with dilute alkali (Houlihan \& Scott, 1972). The mixture was shaken intermittently for $15 \mathrm{~min}$ and neutralized with dilute $\mathrm{HCl}$. The brown precipitate was removed by centrifugation ( $1000 \mathrm{~g}, \mathrm{I}$ o $\mathrm{min}$ ) and the supernatant liquid was diluted with $5 \mathrm{mM}$-phosphate buffer $\mathrm{pH} 7.0$ until the conductivity was less than $3 \mathrm{mS}$. This solution was applied to a $20 \times 0.7 \mathrm{~cm}$ glass column containing DEAE cellulose equilibrated with $5 \mathrm{~mm}$-phosphate buffer $\mathrm{pH} 7 \cdot 0$ and the cellulose washed with two or three volumes of the same buffer. Elution (Io to $15 \mathrm{ml} / \mathrm{h}$ ) was effected with a convex gradient constructed as in Fig. 2.

(ii) $\gamma$-Glutamylcarboxypeptidase treatment. Another portion of the extract was subjected to the action of guinea-pig intestinal mucosa or rat liver 'conjugase' ( $\gamma$-glutamylcarboxypeptidase). The extract was made $0 \cdot \mathrm{I} M$ with respect to a sodium ascorbate buffer pH 4.5 and the 'conjugase' preparation either from guinea-pig mucosa (Bernstein, Gutstein \& Weiner, I969) or from rat liver (Brown, Davidson \& Scott, I974) was added 4: I $(\mathrm{v} / \mathrm{v})$. Incubation was carried out overnight at $37^{\circ} \mathrm{C}$ under a thin layer of toluene. The toluene was removed and the $\mathrm{pH}$ of the extract adjusted to 7.5 with dilute alkali. The extract was then centrifuged ( $1000 \mathrm{~g}$, Io $\mathrm{min}$ ) and diluted with $50 \mathrm{mM}$-tris- $\mathrm{HCl}$ buffer $\mathrm{pH} 7.5$ containing $0.2 \% 2$-mercaptoethanol (MET) until the conductivity was less than $2 \cdot 0 \mathrm{mS}$. This solution was applied to a $30 \times 0.8 \mathrm{~cm}$ glass column of QAE Sephadex equilibrated with $50 \mathrm{~mm}$-tris- $\mathrm{HCl} \mathrm{pH} 7.5$ and eluted with a linear gradient composed of $300 \mathrm{ml}$ each of 50 mM-tris- $\mathrm{HCl}, 0.2 \% \mathrm{MET} \mathrm{pH} 7.5$ and $0.6 \mathrm{M}-\mathrm{NaCl}$ in the same buffer.

Radiochemical methods. The toluene-Triton X-I00 scintillant fluid recommended by Turner (I969) was used throughout at a ratio of I part sample to Io parts scintillation fluid. Radioactivities were determined using a Packard Tri-Carb liquid scintillation spectrometer model 3375 . 


\section{RESULTS}

\section{Radioactive incorporation and extraction}

The uptake of the labelled precursors $\left[{ }^{3} \mathrm{H}\right]$ PteGlu, or $\left[{ }^{14} \mathrm{C}\right] p-\mathrm{AB}$ by the test organisms and the radioactivity subsequently extracted from the stationary phase organisms are summarized in Table I. While $L$. case $i$ showed the greatest percentage absorption of labelled precursor from the medium, $E$. coli with nearly as much absorption gave by far the greatest ease of extraction of biosynthetic folate compounds. The lactic acid bacteria were quite variable in these respects: Streptococcus faecalis, which exhibited good uptake, gave the worst extraction under the conditions used.

Table I. Uptake and extraction of radioactivity from $\left[{ }^{3} \mathrm{H}\right]$ pteroylglutamate or $\left[{ }^{14} \mathrm{C}\right] p$-aminobenzoic acid by different bacteria

$\begin{array}{lccccc}\text { Micro-organism } & \ldots & \begin{array}{c}\text { Strepto- } \\ \text { coccus } \\ \text { Labelled compound }\end{array} & \begin{array}{c}\text { Escherichia } \\ \text { coli }\end{array} & \begin{array}{c}\text { Lactobacillus } \\ \text { casei }\end{array} & \begin{array}{c}\text { Lactobacillus } \\ \text { plantarum }\end{array} \\ \text { Label extracted from bacteria }(\%) & \text { PteGlu } & p \text {-AB } & \text { PteGlu } & p \text {-AB } \\ \text { Label remaining in medium (\%) } & & 22 & 74 & 46 & 26 \\ \text { Label in debris (\%) } & 27 & 24 & 19 & 40 \\ \end{array}$

\section{Streptococcus faecalis folates from $\left[{ }^{3} \mathrm{H}\right]$ PteGlu}

Anion exchange chromatography of $\left[{ }^{3} \mathrm{H}\right]$ folates before and after treatment with guineapig mucosal 'conjugase' showed that almost all the folate from stationary phase $S$. faecalis was conjugated by the addition of further glutamyl residues and that they were primarily formylated derivatives (i.e. $5-\mathrm{CHO}-\mathrm{H}_{4} \mathrm{PteGlu}_{x}$, Io-CHO-H $\mathrm{PteGlu}_{x}$ ) (Fig. I). After $\mathrm{KMnO}_{4}$

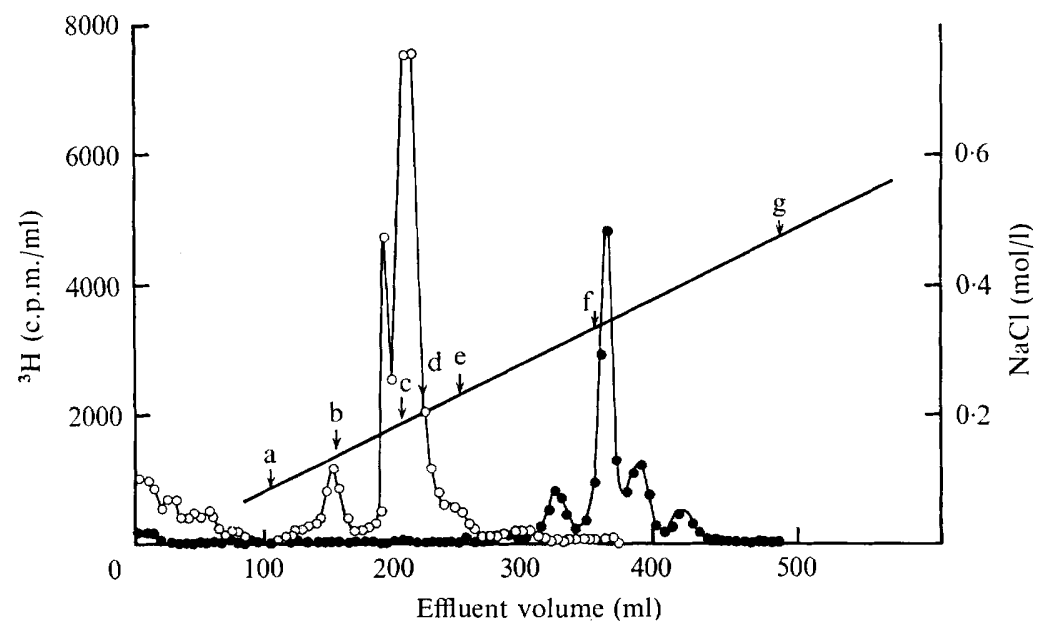

Fig. I. QAE Sephadex chromatography of folate compounds extracted from the folate-requiring strain of $S$. faecalis (NCIB6459). Organisms were grown in folate-deficient medium supplemented with $\left[{ }^{3} \mathrm{H}\right]$ pteroyl-L-glutamate. - Extract; $\mathrm{O}$, extract subjected to guinea-pig mucosal 'conjugase' preparation. Letters indicate approximate positions of standard compounds on linear gradient: (a) $p$-AB, (b) Io-CHO-H $\mathrm{H}_{4} \mathrm{PteGlu}$, (c) $p$-ABGlu, (d) $5-\mathrm{CHO}-\mathrm{H}_{4} \mathrm{PteGlu}$, (e) $5-\mathrm{CH}_{3}-\mathrm{H}_{4} \mathrm{PteGlu}$, (f) PteGlu, (g) Pte Glu ${ }_{7}$. Gradient composed of o to $0.6 \mathrm{M}-\mathrm{NaCl}(2 \times 300 \mathrm{ml})$ in $50 \mathrm{~mm}$-tris-HCl pH 7.5 . Flow rate $20 \mathrm{ml} / \mathrm{h}$ at $20^{\circ} \mathrm{C}$. Standards of (b), (c) and (d) were detected by extinction at $280 \mathrm{~nm}$; the other standards were radioactive. 


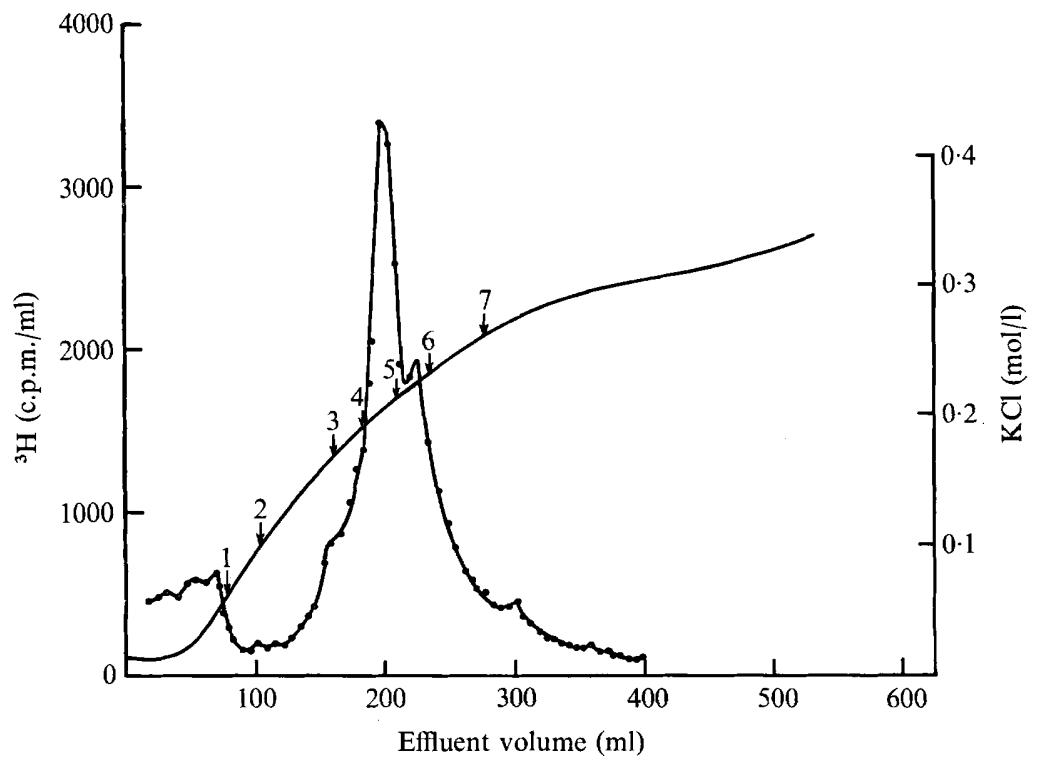

Fig. 2. DEAE-cellulose chromatography of $p$-amino $\left[3^{\prime} 5^{\prime}-{ }^{3} \mathrm{H}\right]$ benzoylpoly- $\gamma$-L-glutamate derivatives obtained by alkaline $\mathrm{KMnO}_{4}$ oxidation of folates from the folate-requiring strain of $S$. faecalis (NCIB6459). Numerals indicate approximate elution positions $( \pm 3 \%)$ of chemically synthesized standard compounds, i.e. $p-\mathrm{ABGlu}_{x}(x=0, \mathrm{I}, \ldots, 7)$. Gradient composed of 0 to $\mathrm{I} \cdot \mathrm{O} \mathrm{M}-\mathrm{KCl}$ $(550 \mathrm{ml}+235 \mathrm{ml})$ in $5 \mathrm{~mm}$-phosphate buffer $\mathrm{pH} 70^{\circ}$. Flow rate 10 to $15 \mathrm{ml} / \mathrm{H}$ at $20^{\circ} \mathrm{C}$.

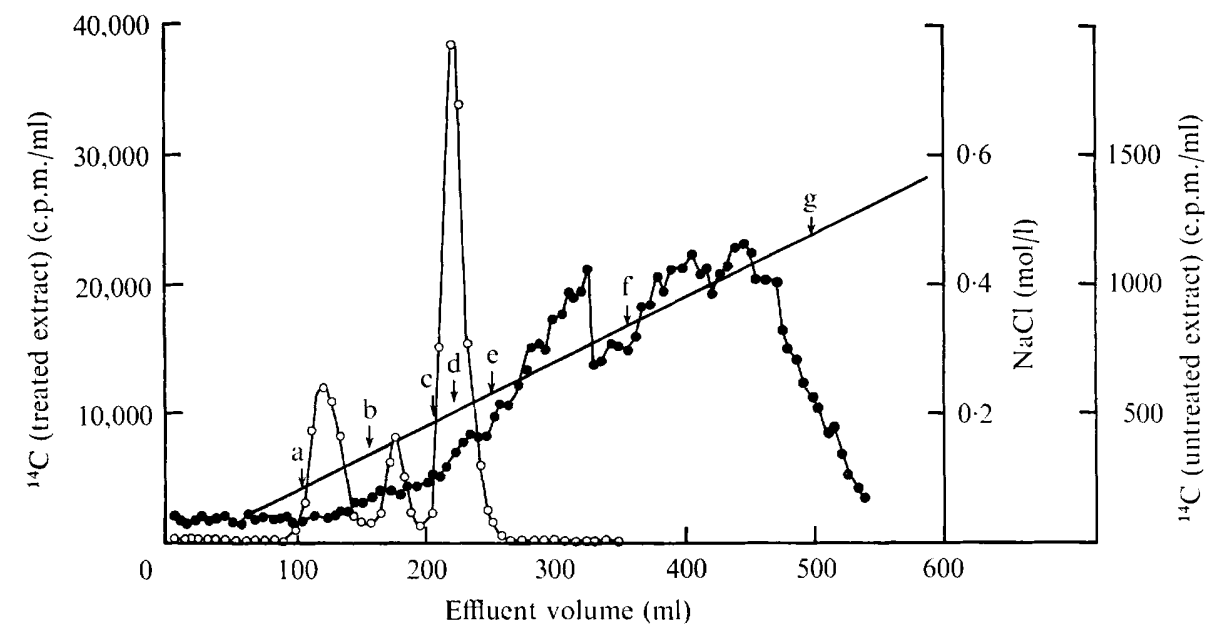

Fig. 3. QAE Sephadex chromatography of folate compounds extracted from a $p$-AB-requiring mutant of $E$. coli (NCIB8IO9). Organisms were grown in defined medium supplemented with $\left[{ }^{14} \mathrm{C}\right] p$-AB. Extract; $O$, extract treated with rat liver 'conjugase' preparation; for other symbols see Fig. I.

oxidation of these folate compounds, the tritiated $p$-aminobenzoylpoly- $\gamma$-L-glutamates produced were mainly derivatives of tetra- and pentaglutamate folates (Fig. 2).

\section{Escherichia coli folates from $\left[{ }^{14} C\right] p-A B$}

The elution profile of the $\left[{ }^{14} \mathrm{C}\right]$ folates extracted is shown in Fig. 3 together with compounds released after treatment with a conjugase preparation from rat liver. After 


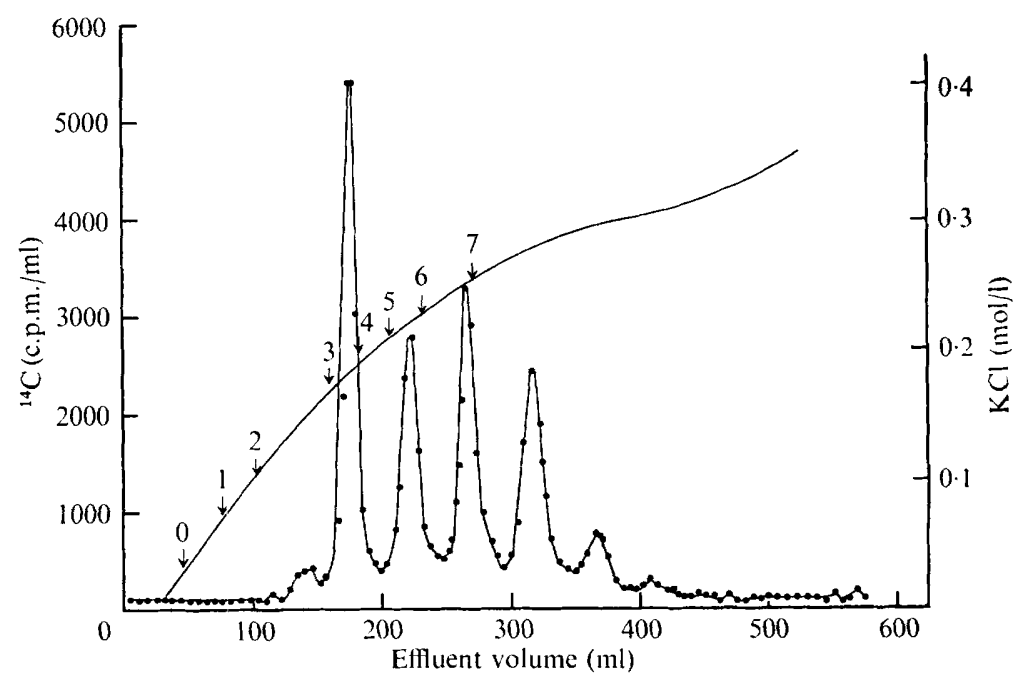

Fig. 4. DEAE-cellulose chromatography of $p$-amino[ $\left.{ }^{14} \mathrm{C}\right]$ benzoyl poly- $\gamma$-L-glutamates obtained by alkaline $\mathrm{KMnO}_{4}$ oxidation of native folates of a $p$-AB-requiring mutant of $E$. coli (NCIB8 109). Other details as in Fig. 2.

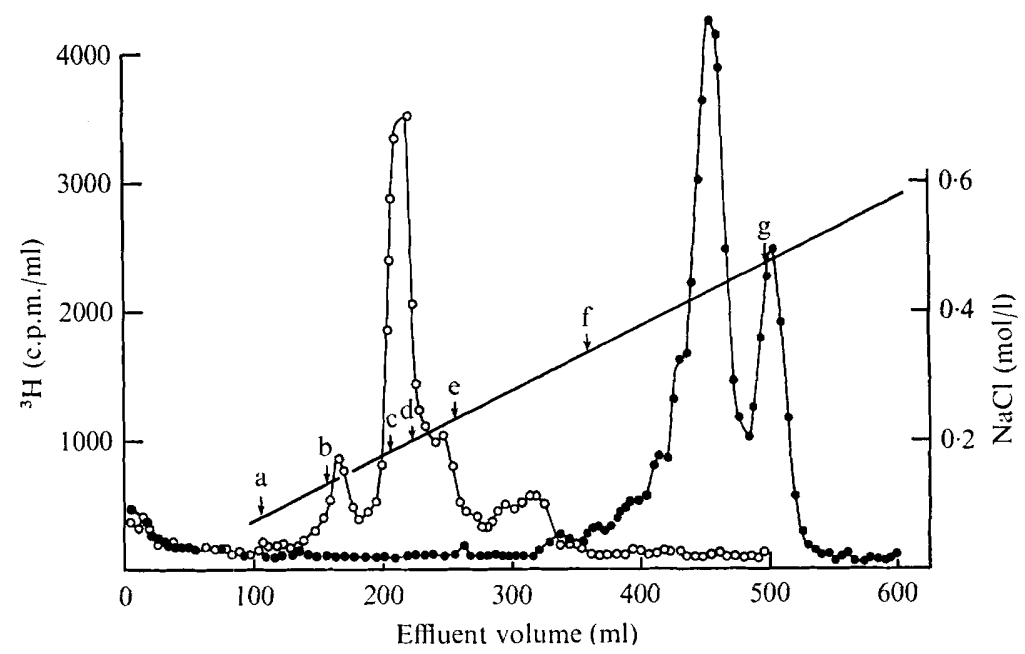

Fig. 5. QAE Sephadex chromatography of folate compounds extracted from the folate requiring strain of $L$. casei (NCIBI 0463 ). Organisms were grown in folate-deficient medium supplemented with $\left[3^{\prime} 5^{\prime} 9-(n)^{-3} \mathrm{H}\right]$ pteroyl-L-glutamate $\mathrm{K}$. - , Extract; $O$, extract subjected to guinea-pig mucosal 'conjugase' preparation. Other details as in Fig. I.

'conjugase' treatment the primary products were $5-\mathrm{CHO}-\mathrm{H}_{4} \mathrm{PteGlu}$ and $\mathrm{IO}-\mathrm{CHO}-\mathrm{H}_{4} \mathrm{PteGlu}$. Chromatography of permanganate-oxidized extracts (Fig. 4) revealed that the predominant $p$-aminobenzoyl[ $\left[{ }^{14} \mathrm{C}\right]$ poly- $\gamma$-glutamate derivatives were probably $p$-ABGlu ${ }_{4}, 6,{ }_{7}$, with lesser quantities of triglutamate and compounds with greater than seven glutamate residues.

\section{Lactobacillus casei folates from $\left[{ }^{3} \mathrm{H}\right]$ PteGlu}

As with $S$. faecalis and $E$. coli the pteroylglutamates resulting from $\left[{ }^{3} \mathrm{H}\right] \mathrm{PteGlu}$ metabolism in $L$. casei are all conjugated. The major product of guinea-pig 'conjugase' action 


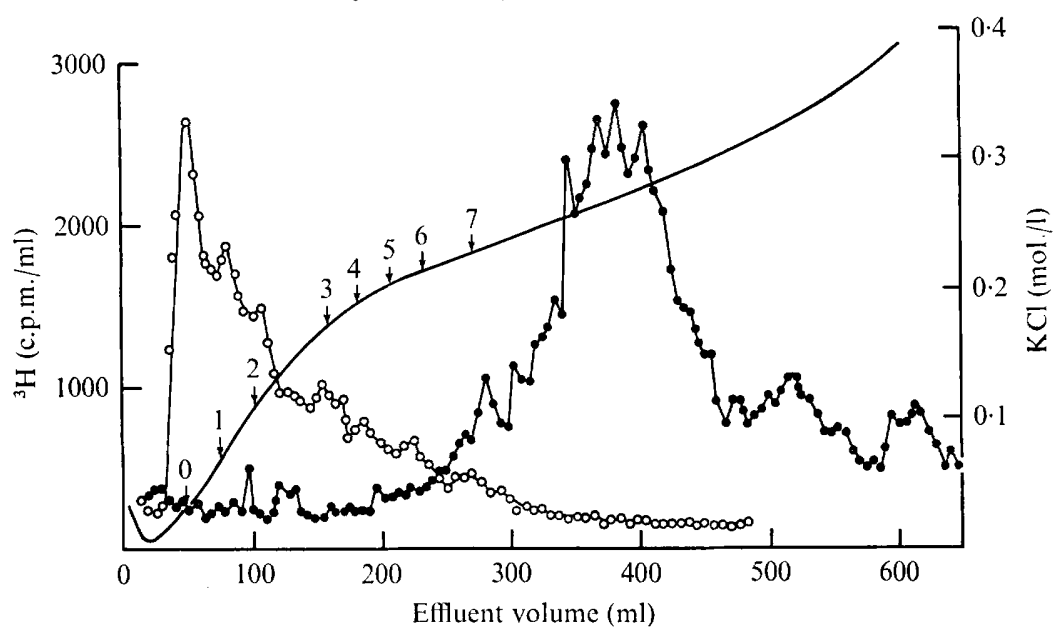

Fig. 6. DEAE-cellulose chromatography of tritiated $p$-aminobenzoylpoly- $\gamma$-L-glutamates from the folate requiring strain of $L$. casei (NCIBI 0463 ) obtained by alkaline oxidation of native folates with $\mathrm{KMnO}_{4}$. ๑, Extract; $\bigcirc$, extract after partial hydrolysis with exogenous guinea-pig 'conjugase" preparation. Other details as in Fig. 2.

appears to be $5-\mathrm{CHO}-\mathrm{H}_{4} \mathrm{PteGlu}$ with smaller amounts of $10-$ formyl- and 5-methyltetrahydropteroylglutamates (Fig. 5). Chromatography on the DEAE-cellulose before and after 'conjugase' treatment showed that polyglutamate derivatives with less than seven glutamyl residues (i.e. eluting before $300 \mathrm{ml}$ ) were absent. The predominant compounds are considerably more acidic and likely to have nine or more glutamate residues, though there are as yet no synthetic standards available for comparison.

\section{Lactobacillus plantarum folates from $\left[{ }^{14} C\right] p-A B$}

A preliminary study of the folate compounds synthesized by this organism indicated that they were essentially similar to those of $L$. casei, most of the ${ }^{14} \mathrm{C}$ activity being associated with derivatives having more than seven glutamyl residues. Small quantities of $p$-AB $\mathrm{Alu}_{6}$, 7 were detected but nothing of shorter chain length.

\section{DISCUSSION}

While numerous workers have reported the occurrence of polyglutamate folates in yeast (Pfiffner et al. 1946; Schertel, Boehne \& Libby, 1965) and various bacteria, e.g. Staphylococcus (Martin \& Koft, I972), Bacillus (Wright, I956), Diplococcus (Sirotnak, Donati \& Hutchinson, 1963), Coxiella (Matthews, Silverman \& Paretsky, 1963), Clostridium (Parker, Wu \& Wood, 1971) and Escherichia (Kozloff \& Lute, 1973), few have employed microbes to synthesize radioactively-labelled folate compounds. Radioactively-labelled biologicallyactive pteroyltriglutamate derivitives, namely $\mathrm{H}_{4} \mathrm{PteGlu}_{3}$ and $\mathrm{IO}-\mathrm{CHO}-\mathrm{H}_{4} \mathrm{PteGlu}_{3}$, have been obtained enzymically from the unlabelled $5, \mathrm{IO}-\mathrm{CH}=\mathrm{H}_{4} \mathrm{PteGlu}_{3}$ of Clostridium acidiurici (Curthoys et al. 1972). At present, enzymic synthesis (either in vitro or in vivo) of formyl substituted or unsubstituted tetrahydropteroylglutamates is the only method of providing biologically active diastereoisomers of these compounds (Nixon \& Bertino, 197I; Matthew \& Huennekens, 1960). Chemically-synthesized racemic methenyltetrahydropteroyl-L-glutamate $\left(5, \mathrm{IO}-\mathrm{CH}_{2}-\mathrm{H}_{4} \mathrm{PteGlu}\right)$ can be resolved chromatographically into its biologically active and inactive diastereoisomers (Yeh \& Greenberg, I965; Kaufman, 
Donaldson \& Keresztesy, I963) and these may in turn be chemically reduced to the corresponding diastereoisomers of 5-methyltetrahydropteroyl-L-glutamate $\left(5-\mathrm{CH}_{3}-\mathrm{H}_{4} \mathrm{PteGlu}\right)$ (Rudiger, 1970; Weir, Brown, Freedman \& Scott, 1973).

Chromatographic separation of pteroylpoly- $\gamma$-L-glutamates having differing numbers of glutamate residues, degrees of reduction with respect to the pterin nucleus and a variety of substituents on the $\mathrm{N}_{5}$ and/or Nio position is probably impossible to achieve by existing techniques (Shin et al. 1972). However, if the variation is confined to either the degree of conjugation or to the type of substitution and reduction, chromatographic separation becomes possible as evidenced by the present study employing either chemical oxidation of the $\mathrm{C} 9-\mathrm{N}$ Io bond or enzymic hydrolysis of $\gamma$-peptide bonds.

It appears that useful approaches to the synthesis of substituted reduced pteroylpolyglutamates could be based on the synthetic properties of the bacteria described in this paper. High specific activity ${ }^{3} \mathrm{H}$-labelled or lower specific activity ${ }^{14} \mathrm{C}$-formyl derivatives with four to seven glutamate residues could be synthesized by $E$. coli or $S$. faecalis and separated chromatographically after conversion to I0-formyltetrahydropteroylglutamates by acidification and neutralization (Houlihan, Davidson, Scott \& Brown, 1973). The advantage of using the latter organism is its apparent inability to synthesize or use methylated folates (McElwee \& Scott, 1972). Methylated derivatives could be obtained by chemical reduction (Chanarin \& Perry, 1967) of the formyl derivatives after isolation or, in the case of mixtures of formyl and methyl derivatives (e.g. L. casei), before separation.

We thank the Biomedical Trust for its support.

\section{REFERENCES}

Baugh, C. M., Stevens, J. C. \& Krumdieck, C. L. (1970). Studies on $\gamma$-glutamyl carboxypeptidase. I. The solid phase synthesis of analogues of pteroylglutamates of folic acid and their effects on human liver $\gamma$-glutamyl carboxypeptidase. Biochimica et biophysica acta 212, 1 I6-125.

BaUgh, C. M. \& Krumdieck, C. L. (197I). Naturally occurring folates. Annals of the New York Academy of Sciences 86, 7-27.

Bernstein, L. H., Gutstein, S. \& Weiner, S. (I969). Folic acid conjugase: inhibition by unconjugated dihydroxy bile acids. Proceedings of the Society for Experimental Biology and Medicine 132, I $167-1169$.

BLAIR, J. A. \& SAUNDERS, K. J. (I970). A convenient method for the preparation of $d l$-5-methyltetrahydrofolic acid (dl-5-methyl-5,6,7,8-tetrahydropteroyl-L-monoglutamic acid). Analytical Biochemistry 34, 376-38I.

Brown, J. P., Davidson, G. E. \& Scott, J. M. (1974). The identification of the forms of folate found in the liver, kidney and intestine of the monkey and their biosynthesis from exogenous pteroylglutamate (folic acid). Biochimica et biophysica acta 343, 78-88.

Brown, J. P., Scott, J. M., Foster, F. G. \& Weir, D. G. (1973). Ingestion and absorption of naturally occurring pteroylmonoglutamates (folates) in man. Gastroenterology 64, 223-232.

Brown, G. M., Weisman, R. A. \& Molnar, D. A. (196I). The biosynthesis of folic acid. I. Substrate and cofactor requirements for enzymatic synthesis by cell extracts of Escherichia coli. Journal of Biological Chemistry 236, 2534-2543.

Chanarin, I. \& Perry, J. (1967). A simple method for the preparation of 5-methyltetrahydropteroylglutamic acid. Biochemical Journal ro5, 633-634.

CuRthoys, N. P., Scott, J. M. \& Rabinowitz, J. C. (I972). Folate coenzymes of Clostridium acidi-urici. The isolation of $(l)-5$, Io-methenyltetrahydropteroyltriglutamate, its conversion to $(l)$-tetrahydropteroyltriglutamate and $(l)$-Io- $\left({ }^{14} \mathrm{C}\right)$ formyltetrahydropteroyltriglutamate and the synthesis of $(l)$-Io-formyl$\left(6,7^{-3} \mathrm{H}_{2}\right)$ tetrahydropteroyltriglutamate and $(l)-\left(6,7^{-}{ }^{3} \mathrm{H}_{2}\right)$ tetrahydropteroyltriglutamate. Journal of Biological Chemistry 247, 1959-1964.

Freed, M. (I966). Methods of Vitamin Assay, 3rd edn, p. 236. New York: Interscience Publishers.

Griffin, M. J. \& Brown, G. M. (I964). The biosynthesis of folic acid. III. Enzymatic formation of dihydrofolic acid from dihydropteroic acid and of tetrahydropteroylglutamic acid compounds from tetrahydrofolic acid. Journal of Biological Chemistry 239, 310-316. 
Houlihan, C. M., Boyle, P. H. \& Scott, J. M. (1972). Preparation and purification of pteroic acid from folic acid. Analytical Biochemistry 46, I-6.

Houlihan, C. M., Davidson, G. E., Scott, J. M. \& Brown, J. P. (I973). Distribution of pteroylpoly- $\gamma-$ Lglutamates in rat liver. Biochemical Society Transactions I, 297-299.

Houlihan, C. M. \& ScotT, J. M. (1972). The identification of pteroylpentaglutamate as the major folate derivative in rat liver and the demonstration of its biosynthesis from exogenous $\left({ }^{3} \mathrm{H}\right)$ pteroylglutamate. Biochemical and Biophysical Research Communications 48, 1675-I68I.

JAEniCKe, L. \& Chan, P. C. (I960). Die Biosynthese der Folsaure. Angewante Chemie 72, 752-753.

Katsunuma, N. \& Shoda, A. (1958). Folic acid synthesising system in Mycobacterium avium. Chemical Abstracts 52, 6488 .

Kaufman, B. T., Donaldson, K. O. \& Keresztesy, J. C. (1963). Chromatographic separation of the diastereoisomers of $d l_{\text {-L-5, }}$, O-methylenetetrahydrofolate. Journal of Biological Chemistry 238, 1498I 500 .

Kozloff, L. M. \& Lute, M. (I973). Bacteriophage tail components. IV. Pteroyl polyglutamate synthesis in T4D-infected Escherichia coli в. Journal of Virology 11, 630--636.

Krumdieck, C. L. \& BaUgh, C. M. (1969). The solid phase synthesis of polyglutamates of folic acid. Biochemistry 8, $1568-1572$.

LAmpen, J. O., Jones, M. J. \& Roepke, R. R. (1949). Mutant strains of Escherichia coli unable to synthesise p-aminobenzoic acid. Journal of Biological Chemistry $\mathbf{1 8 0}, 432-434$.

LEwIS, J. C. (1942). A Lactobacillus assay method for $p$-aminobenzoic acid. Journal of Biological Chemistry I46, $44 \mathrm{I}-450$.

Martin, E. L. \& Koft, B. M. (1972). The formation of rhizopterin and formylated folate polyglutamates during growth of Staphylococcus epidermidis. Canadian Journal of Microbiology 18, 833-839.

Matthew, C. K. \& Huennekens, F. M. (1960). Enzymic preparation of the $l$, L-diastereoisomer of tetrahydrofolic acid. Journal of Biological Chemistry 235, 3304-3307.

Matthews, M.S., Silverman, M. \& Paretsky, D. (1963). Studies on the physiology of Rickettsiae. IV. Folic acids of Coxiella burnettii. Journal of Bacteriology 85, 37-4I.

McElwee, P. G. \& Scott, J. M. (I972). Folate metabolism in Streptococcus faecalis. Biochemical Journal I27, $90 \mathrm{I}-905$.

Merola, A. J. \& Koft, B. W. (1960). Sulfonamide inhibition of folic acid synthesis in a cell-free system. Bacteriological Proceedings, 175.

Millbank, L., Davis, R. E., Rawlins, M. \& Waters, A. H. (1970). Automation of the assay of folate in serum and whole blood. Journal of Clinical Pathology 23, 54-59.

Nixon, P. F. \& Bertino, J. B. (197I). Enzymatic preparations of radio-labelled (+)-L-5-methyltetrahydrofolic acid and (+)-L-5-formyltetrahydrofolate. Analytical Biochemistry 43, I62-I 72.

O'Broin, J. D., Scott, J. M. \& Temperley, I. J. (1973). A comparison of serum folate estimations using two different methods. Journal of Clinical Pathology 26, 80-8 I.

Ortiz, P. J. \& Hotchkiss, R. D. (1966). The enzymatic synthesis of dihydrofolate and dihydropteroate in cell free preparations from wild-type and sulfonamide-resistant pneumococcus. Biochemistry $\mathbf{5}, 67-73$.

PARker, D. J., WU, T. P.\&Wood, H. G. (I971). Total synthesis of acetate from $\mathrm{CO}_{2}$ : methyltetrahydrofolate, an intermediate and a procedure for separation of the folates. Journal of Bacteriology 108, 770-776.

Pfiffner, J. J., Calkins, D. G., Bloom, E. S. \& O'Dell, B. L. (1946). On the peptide nature of vitamin B conjugate from yeast. Journal of the American Chemical Society 68, 1392.

ReYnolds, J. J. \& BRown, G. M. (I964). The biosynthesis of folic acid. IV. Enzymatic synthesis of dihydrofolic acid from guanine and ribose compounds. Journal of Biological Chemistry 239, 317-325.

Rudiger, H. (1970). The relative configuration of $\mathrm{N}^{5}$-methyl-L-tetrahydrofolic acid. FEBS Letters II, 265267.

Schertel, M. E., Boehne, J. W. \& LibBy, D. A. ( 1965). Folic acid derivatives in yeast. Journal of Biological Chemistry 240, 3154-3I58.

Sirotnak, F. M., Donati, G. J. \& Hutchinson, D. J. (I963). Folic acid derivatives synthesised during growth of Diplococcus pneumoniae. Journal of Bacteriology 85, 658-665.

Shin, Y. S., Buehring, K. U. \& Stokstad, E. L. R. (1972). Separation of folic acid compounds by gel chromatography on Sephadex G-15 and G-25. Journal of Biological Chemistry 247, 7266-7269.

Shiota, T. \& Disraely, M. N. (I96I). The enzymic synthesis of dihydrofolate from 2-amino 4-hydroxy-6hydroxymethyldihydropteridine and p-aminobenzoylglutamate by extracts of Lactobacillus plantarium. Biochimica et biophysica acta 52, 467-473.

TurNER, J. C. (1969). Tritium counting with Triton X-Ioo scintillant. International Journal of Applied Radiation and Isotopes 20, 499-505. 
WeIR, D. G., Brown, J. P., FreEdMAN, D. S. \& ScotT, J. M. (I973). The absorption of the diastereoisomers of 5-methyltetrahydropteroylglutamate in man: a carrier-mediated process. Clinical Science and Molecular Medicine 45, 625-631.

Weisman, R. A. \& Brown, G. M. (1964). The biosynthesis of folic acid. V. Characteristics of the enzyme system that catalyzes the synthesis of dihydropteroic acid. Journal of Biological Chemistry 239, 326-33I.

WRIGHT, B. E. (1956). The role of polyglutamyl pteridine co-enzymes in serine metabolism. II. A comparison of various pteridine derivatives. Journal of Biological Chemistry 219, 873-883.

YeH, Y. C. \& GreENBERG, D. M. (1965). Purification and properties of $\mathrm{N}^{5}, \mathrm{~N}^{10}$ methylenetetrahydrofolate dehydrogenase of calf thymus. Biochimica et biophysica acta 105, 279-291. 